\title{
Opinion paper: Are we on the right track toward livestock sector sustainability?
}

\author{
I. Köhler-Rollefson ${ }^{1 \dagger}$ and D. Steane ${ }^{2}$ \\ ${ }^{1}$ League for Pastoral Peoples and Endogenous Livestock Development, Pragelatostr. 20, 64372 Ober-Ramstadt, Germany; ${ }^{2} 99$ Moo 7, Thakwang, Saraphi, \\ Chiang Mai 50140, Thailand
}

First published online 13 July 2017

The sustainability of the livestock sector is a global concern; as remedy international agencies such as Food and Agriculture Organization and Worldbank promote the improvement of natural resource use efficiency, aiming to reduce greenhouse gas emissions per unit of livestock product. However, this approach neglects other crucial aspects of overall sustainability such as public health (use of antibiotics), economic and social sustainability, biodiversity and animal welfare. We argue that, depending on geographical and socio-economic context, there can even be a negative correlation between natural resource use efficiency (which is the ratio between the amount of natural resource inputs and a given quantity of output) and other aspects of sustainability.

It is the efficient high-input livestock systems which have led to enormous global imbalances of nutrients, particularly nitrogen and phosphorous, and pose severe threats to human health and biodiversity. For instance, the intensification of pig systems in Spain has led to a threefold increase in reactive nitrogen inputs, from $536 \mathrm{Gg} \mathrm{N}$ year in 1961 to 1965 to $1673 \mathrm{Gg} \mathrm{N}$ in 2005to 2009, entailing considerable pollution by local emissions of reactive nitrogen forms to air and water (Lassaletta et al., 2014).

One, perhaps more useful, way of evaluating protein efficiency that takes into account sustainability concerns is the human-edible protein balance (H-EPB), an index value that represents the edible protein output that is produced per unit of human-edible protein input that was required to produce it. When comparing H-EPB on a country-by-country basis, countries with 'old-fashioned' and 'inefficient' pastoralist systems are in the lead, whereas the so-called efficient systems trail far behind. Kenya for instance produces 20 times as much animal protein as it uses to feed its livestock, whereas the United States feeds twice as much protein to its livestock as it produces, with European countries not far behind (Food and Agriculture Organization, 2011). This raises serious considerations in terms of the availability of protein for human consumption.

Efficiency is often suggested to be achieved by switching to 'High-performing animals, making use of improved

\footnotetext{
${ }^{\dagger}$ E-mail: ilse@pastoralpeoples.org
}

genetics, balanced feed, and nutrition, and good animal health and husbandry which will help to reduce methane emissions per unit of output' (Steinfeld et al., 2010). However, switching to high-performing animals and making use of 'improved genetics' ignores the advantages of locally adapted breeds in adapting to climate change. High-yielding breeds are particularly vulnerable to climate change and achieve high yields by consuming human foods. Given the predictions regarding reduced yields of human food crops and the warnings of plant breeders of not being able to cope with such changes as well as the general consideration of increasing human population, the use of such breeds would appear to be a disastrous course to take.

When we look at economic sustainability, we note that some of the natural resource efficient systems depend on enormous subsidies for feed production and exotic genetics, placing burden on tax payers in developed countries. The natural resource use efficient livestock systems in North America and Europe are heavily supported by the taxpaying public, especially through subsidies for maize and soybeans, the main ingredients of livestock diets in intensive systems. In the United States, livestock subsidies amounted to USD 8.6 billion, corn subsidies to USD 94 billion and soybean subsidies to USD 32 billion in the period from 1995 to 2011. By contrast, livestock producers in developing countries using locally adapted livestock as means of production receive no subsidies. Only the use of exotic germplasm may be either subsidized or supported by the availability of loans.

It is evident that efficient systems achieved by biological economies of scale, i.e., higher production levels are not always beneficial for rural economies. Although the need for 'inclusive' livestock development is widely recognized, including in the Global Agenda for Sustainable Livestock, the correlation between the natural resource as efficient systems and social sustainability is largely negative. In the United States, rural poverty is higher in areas where animal industries are located. In Germany, the number of dairy farmers has reduced by $>90 \%$ in the last 50 years from 1365000 to 110000 in 2005 . The same trends are manifesting themselves in countries with 'emerging economies' where the 
Livestock Revolution has taken hold. In China, the spread of industrial pork production has been accompanied by a significant reduction in the numbers of small farmers. Until 1985, backyard farmers raising less than five pigs per year produced at least $95 \%$ of the country's pork on their small holdings of land measuring about half an acre. However, now these smallholder farmers find it difficult to access markets and are not in a position to meet the required standards. A mass urban migration is taking place in which men migrate to the big cities, whereas the elderly, women and children remain behind.

On the consumer end, industrial livestock production is rejected by a growing proportion of urban consumers, leading to a rapid rise in vegetarianism and veganism. The number of vegans in the United Kingdom increased from 150000 in 2006 to 542000 in 2016 or by $350 \%$. According to the Vegetarian and Vegan Association of Germany there are currently 8 million vegetarians and 1.3 million vegans in Germany.

In order to make progress on reducing air, soil and water pollution, creating rural employment and improving animal welfare, in some regions of the world there appears to be a real and important need to counter the strong current trend toward larger and larger landless livestock holdings and instead decentralize and decongest livestock keeping. Furthermore, we need to increase the utilization of non-human-edible foods. An extensive study evaluating different scenarios based on the use/non-use of human-edible foods given to livestock shows that comprehensive gains would be made by avoiding use of human-edible foods, including reduction of greenhouse gas emissions by $18 \%$, occupation of arable land by $26 \%$, $\mathrm{N}$-surplus by $46 \%$; P-surplus by $40 \%$, pesticide use intensity by $22 \%$ and freshwater use by $21 \%$ (Schader et al., 2015).

How to achieve this? One potential approach in certain developing countries would be to put into place policies that give preference to land-based livestock production and optimize use of locally available biomass, such as crop residues and/or the natural vegetation available on common property resources by means of lower-input, more resilient livestock breeds. This will not only prevent small-scale and medium-sized livestock keepers from being squeezed out but also reduce nutrient imbalances, lower disease pressure, reduce use of antibiotics and conserve biological diversity as well as maintaining and creating jobs and livelihoods in rural areas. Although not all small-scale livestock keepers can or want to stay in this occupation, care must be taken to not take away their livelihoods before alternatives are available.

The following two broad strategies for achieving such a scenario can be proposed.

First, the environmental costs of livestock production must be included so that the real cost of food can be properly identified. Such efforts are already being undertaken but require greater investment due to the urgent need for this kind of data. Such real cost information would probably lead to the opportunity to increase extensification to make optimal use of all local biomass and reduce feeding humanedible foods to livestock. In developing countries, one of the mechanisms for this would be to codify the customary rights of pastoralists and other livestock keepers to common pool resources. In addition, in developing countries, the attraction of extensive livestock keeping as a profession must be upgraded, for instance, by initiatives to create cooperatives and strengthen social networks and exchange. This strategy would be dependent on locally adapted livestock breeds and lead to their revival, thereby contributing to biodiversity conservation. In Europe, dairy and pig farmers must be encouraged to extensify, a move that may even improve farm income as has been shown for Dutch pig and dairy farmers by saving on external inputs and by enabling them to achieve price premiums on their products (van Grinsven et al., 2015).

The subsidies that are currently directed toward the support of monoculture cultivation and the setting up of industrial systems must be redirected toward payment for environmental services by locally adapted livestock keepers and toward the setting up of value chains. Although this will affect costs and availability of livestock products, this may not be an entirely undesirable effect, considering the negative health effects of livestock product overconsumption. The situation will differ between developed and developing countries, but for Europe it has been shown that the extensification of agriculture in combination with adjusted diets (cutting production and consumption of livestock products by $50 \%$ ) and externalization of environmental costs to food prices would still allow the EU to be a food exporter while reducing land demand outside Europe by $2 \%$ (van Grinsven et al., 2015).

In conclusion, a more comprehensive approach than increasing natural resource use efficiency needs to be adopted to move the global livestock sector toward more sustainability. The current focus ignores the negative externalities of natural resource use efficient livestock production systems with respect to biodiversity conservation, public health, the nutritional quality of livestock products and animal welfare.

\section{Acknowledgments}

The authors thank John Hodges, Evelyn Mathias, Kamal Kishore and other LIFE Network members for discussions that led to this paper. Some of the background research was supported by Misereor. The authors would also like to thank three anonymous reviewers whose comments significantly improved the quality of this paper.

\section{References}

Food and Agriculture Organization 2011. World livestock 2011. Livestock in food security. FAO, Rome, Italy.

Lassaletta L, Billen G, Romero E and Aguilar E 2014. How changes in diet and trade patterns have shaped the N cycle at the national scale: Spain (1961-2009). Regional Environmental Change 14, 785-797.

Schader C, Muller A, El-Hage Scialabba N, Judith Hecht J, Isensee A, Erb KH, Smith P, Makkar HPS, Klocke P, Leiber F, Schwegler P, Stolze M and Niggli U 2015. Impacts of feeding less food-competing feedstuffs to livestock on global food system sustainability. Journal Royal Society Interface 12, 20150891.

Steinfeld H, Gerber P and Opio C 2010. Responses on environmental issues. In Livestock in a changing landscape, volume I, (ed. H Steinfeld, et al.), pp. 311-322. Island Press, Washington D.C., USA.

Van Grinsven HJM, Erisman JW, de Vries W and Westhoek H 2015. Potential of extensification of European agriculture for a more sustainable food system, focusing on nitrogen. Environmental Research Letters 10, 2. 